\title{
Synthesis of Some Substituted Benzoxazole [3,4-b] imidazoles
}

\author{
Yaser S. Al-Jawharji \\ Chemistry Dept., College of Education, \\ University of Mosul
}

Received

23 / 07 / 2007
Accepted

05 / $11 / 2007$

\begin{abstract}
الملخص
مة في هذا البمث تحضير عدد من معوضلت الميدازول [b-4,3] 4 -اريل هكساهيدرو

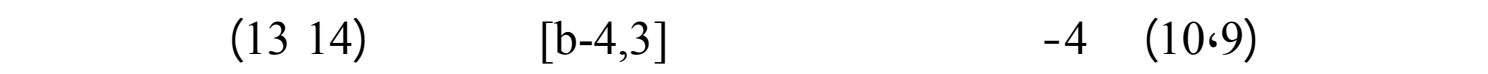

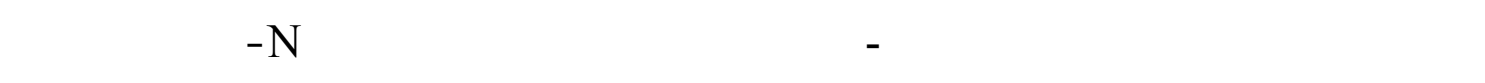

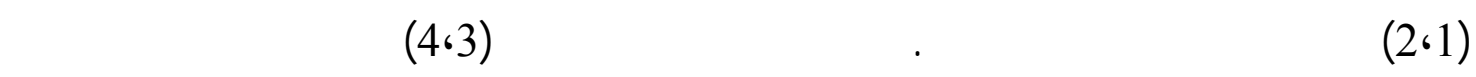

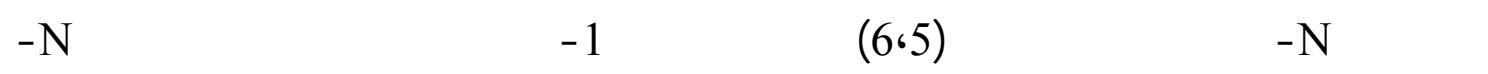

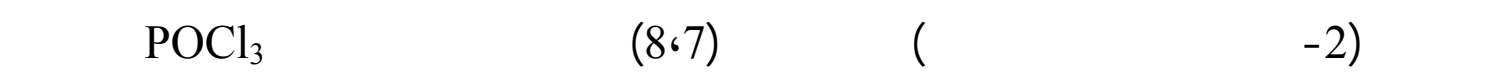

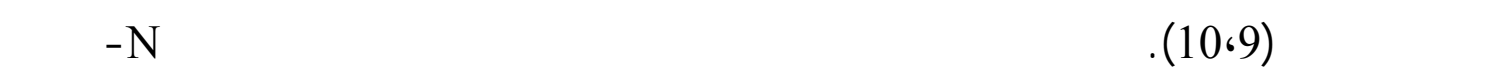
(2-بنزوكسازولو) اريل لمايد (12،11) ليفاعل بدورو مع
\end{abstract}

مُ التلكد من صحة ترلكيب جمبع المركبلت المحضرة من خلال المعلوملت الفيزيائية والطيفية.

\section{ABSTRACT}

In this paper the synthesis of 4-substituted benzoxazole [3,4-b] imidazole $(9,10)$ and 4-aryl hexahydrobenzoxazole $[3,4-b]$ imidazole $(13,14)$ is reported. Glycine was treated with benzoyl chloride or p-nitrobenzoyl chloride to give $\mathrm{N}$-aroyl glycine $(1,2)$, the reaction of $\mathrm{N}$-aroyl glycine with thionyl chloride followed by treatment the product $(3,4)$ with ammonium hydroxide to give $\mathrm{N}$-aroyl glycine amide $(5,6)$. Treatment of the amide with 1-bromocyclohexanone gave N-methylene-2-hexahydrobenzoxazole) aryl 
amide $(7,8)$, cyclization of this gave product $(9,10)$, whereas the compounds $(13,14)$ was synthesized from o-aminophenol and the acid chlorides to give $\mathrm{N}$-methylene (2-benzoxazole) aryl amide $(11,12)$ which cyclized with phosphorous oxychloride to give the products $(13,14)$.

The structure of all synthesized compounds were confirmed by physical and spectral data.

\section{INTRODUCTION}

The preparation of 2-methyl benzoxazole by Ladenbyrg (1876) marks the first recognition of oxazole ${ }^{(1)}$, but the name of these compounds comes from Hantzsch (1887) when gave that name to this class of compounds ${ }^{(2)}$.<smiles>c1cocn1</smiles>

Oxazole<smiles>c1ccc2ocnc2c1</smiles>

Benzoxazole

Benzoxazoles are formed by the action of potassium amide in liquid ammonia of $\mathrm{N}$-aroyl derivatives of both o-and $\mathrm{m}$-chloroaniline ${ }^{(3)}$.

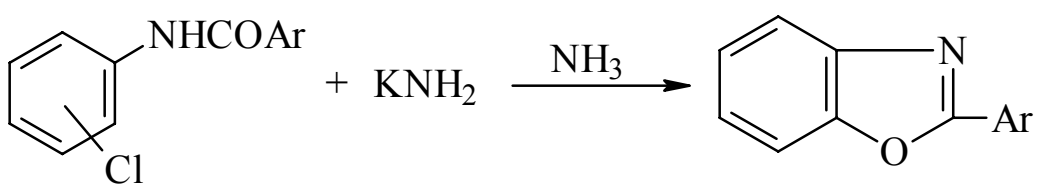

Benzoxazole may be prepared by the reaction between oaminophenols and carboxylic acid $^{(4)}$ as a simple method.

There are few examples of solid-phase synthesis of benzoxazoles heterocycles using a similar strategy of cyclization of the corresponding 2aminophenol, benzoxazole formation was initially envisioned to take place between the solid-supported aminophenol with the diversity element introduced as a carboxylic acid ${ }^{(5)}$.

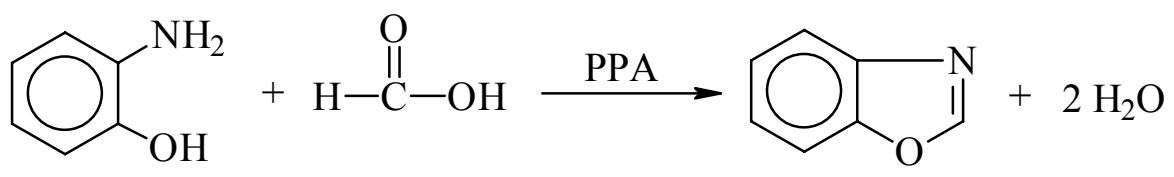


Benzoxazoles and other condensed oxazoles are obtained by oxidative ring-closure of phenolic Schiff's bases ${ }^{(2)}$.

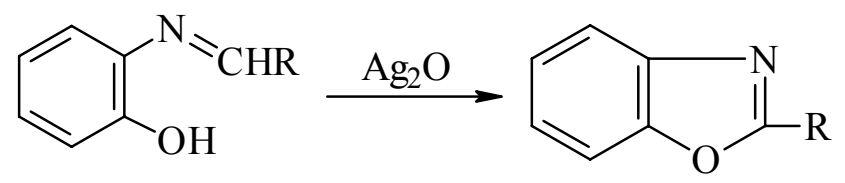

Aromatic polybenzoxazole are another class of heterocyclic polymer that exhibit excellent thermooxidative stability, high-tensile modulus and strength and superior chemical resistance. A few rigid-rod polybenzoxazole are reported to have potential for fabrication into high-modulus highstrength fiber ${ }^{(6)}$.

It was known that poly (benzoxazole) $)_{\mathrm{s}}$ is among the most thermally stable polymers containing high-rigid heterocycles in the Backbon ${ }^{(7)}$.

In other side some of benzoxazole compound have activity against the bacteria and fungi ${ }^{(8)}$ and anticancer activity ${ }^{(9)}$, for example zoxazolamine have effective against a wide range of enteric infections ${ }^{(2)}$.<smiles>Nc1nc2ccccc2o1</smiles>

\section{EXPERIMENTAL}

All chemicals were purchased from Flucka and BDH Chemical Ltd. The melting points were measured on an Electrothermal 9300 Engineering LTD and were uncorrected. IR spectra were recorded on Infrared Spectrophotometer Model Tensor 27, Bruker Co., Germany, using $\mathrm{KBr}$ discs. UV spectra were recorded on Shimadzu Double-Beam Spectrophotometer UV-210 A using chloroform as a solvent.

\section{Preparation of $\mathrm{N}$-aroyl glycine $(\mathbf{1 , 2})^{(10)}$}

$(0.02 \mathrm{~mol}, 1.5 \mathrm{~g})$ of glycine in $20 \mathrm{ml}$ of $1 \mathrm{~N}$ sodium hydroxide was cooled at $0-5{ }^{\circ} \mathrm{C}$ and the cold solution was added dropwise to a solution of $(0.02 \mathrm{~mol})$ of acid chloride in $(30 \mathrm{ml})$ of chloroform. The reaction mixture was continued under stirring for an additional an hour. The aqueous layer 
was separated and acidified with $2 \mathrm{~N}$ hydrochloric acid. The solid product was filtered by filtration and washed with water. The physical properties and spectral data are listed in Tables (1 and 2).

\section{Preparation of N-aroyl glycine chloride $(3,4)^{(11)}$}

Thionyl chloride $(10 \mathrm{ml})$ was added to $(0.025 \mathrm{~mol})$ of compound $(1,2)$ the mixture was refluxed for $30 \mathrm{~min}$. in a water bath with stirring until the releasing of hydrochloric acid stopped. The reaction mixture was cooled and the formed solid was collected by filtration. The physical properties and spectral data are listed in Tables (1 and 2).

\section{Preparation of $\mathrm{N}$-aroyl glycine amide $(5,6)^{(12)}$}

Ammonium hydroxide solution $(10 \mathrm{ml})$ was added to $(0.01 \mathrm{~mol})$ of compound $(3,4)$ with stirring for $10 \mathrm{~min}$ and the formed solid was collected by filtration and recrystallized from ethanol-water. The physical properties and spectral data are listed in Tables (1 and 2).

Preparation of $\mathrm{N}$-methylene(2-hexahydrobenzoxazole) aryl amide $(\mathbf{7 , 8})^{(13)}$

To $(0.06 \mathrm{~mol}, 10.5 \mathrm{~g})$ of 1-bromocyclohexanone in $(40 \mathrm{ml})$ of ethanol was added $(0.06 \mathrm{~mol})$ of $(5,6)$ and the reaction mixture was refluxed for 17 hours. Then the reaction mixture was cooled and the precipitate was filtered, washed with petroleum ether and dried and crystallized from ethanol-water. The physical and spectral data are listed in Tables (1 and 2).

\section{Preparation of 4-aryl hexahydrobenzoxazolo[3,4-b]amidazole $(9,10)^{(9,12)}$}

To $(0.01 \mathrm{~mol})$ of compound $(7,8)$ soluble in $(25 \mathrm{ml})$ of benzene $(20 \mathrm{ml})$ of phosphorous oxychloride was added and the mixture was refluxed for 4 hours. The reaction mixture was treated with ice-water and extracted with methylene chloride and dried. The product was recrystallized from etherpetroleum ether. The physical properties and spectral data are listed in Tables (1 and 2).

\section{Preparation of N-methylene (2-benzoxazolo) aryl amide $(11,12)^{(14)}$}

$(0.01 \mathrm{~mol}, 1 \mathrm{~g})$ of o-aminophenol in $(25 \mathrm{ml})$ methylene chloride was added to $(0.01 \mathrm{~mol})$ of compound $(3,4)$ was added and the reaction mixture was refluxed for 7 hours. The product was distilled under vacuum to give the compound (11) which was recrystallized by ether-petroleum ether. The physical and spectral data are listed in Tables(1 and2). 


\section{Preparation of 4-substituted benzoxazole $[3,4-b]$ imidazole $(13,14)^{(10,14)}$}

To $(0.01 \mathrm{~mol})$ of $(11,12)$ soluble in $(25 \mathrm{ml})$ benzene was added $(20 \mathrm{ml})$ of phosphorous oxychlirde and refluxed for 4 hours. The reaction mixture was treated with ice-water and extracted with methylene chloride and dried. The product was recrystallized from ether-petroleum ether. The physical and spectral data are listed in Tables (1 and 2).

\section{RESULTS AND DISCUSSION}

In this paper the synthesis of 4-substituted benzoxazole [3,4-b] imidazole $(13,14)$ and 4-aryl hexahydrobenzoxazole $[3,4-b]$ imidazole $(9,10)$ from glycine and benzoyl chloride is reported (Scheme 1). Glycine was treated with benzoyl or 4-nitrobenzoyl chloride to give $\mathrm{N}$-aroyl glycine $(1,2)$, IR spectra of compound (1) show absorption peak $v \mathrm{~cm}^{-1}$ at 1745 and $1600(2 \mathrm{C}=\mathrm{O}), 3341(\mathrm{O}-\mathrm{H}), 1181(\mathrm{C}-\mathrm{O})$. Compounds $(1$ and 2) were converted to its acid chloride by their reaction with thionyl chloride. The IR spectra of compound (3) shows absorption peaks at $1770,1690 \mathrm{~cm}^{-1}(2 \mathrm{C}=\mathrm{O})$ and $3445(\mathrm{~N}-\mathrm{H})$. The acid chlorides (3 and 4) were treated with ammonium hydroxide solution to give the corresponding amides $(5,6)$, there amides show absorption peak at $v \mathrm{~cm}^{-1} 3410(\mathrm{~N}-\mathrm{H})$ and $1645(\mathrm{C}=\mathrm{O})$. Compounds $(5$ and 6) were treated with 1-bromocyclohexanone in ethanol to give $\mathrm{N}$ methylene (2-hexahydro-benzoxazole) aryl amide (7 and 8). The IR spectra for compound (7) shows absorption peaks $v^{-1}$ at $3422(\mathrm{~N}-\mathrm{H}), 1636$ $(\mathrm{C}=\mathrm{N}), 1653(\mathrm{C}=\mathrm{O})$ and $1031(\mathrm{C}-\mathrm{O})$. The cyclization of compounds $(7$ and 8) with phosphorous oxychloride (dehydrations agent) gave 4-aryl hexahydrobenzoxazole $[3,4-b]$ amidazole $(9,10)$.

Whereas the reaction of acid chlorides ( 3 and 4 ) with o-aminophenol in methylene chloride gave $\mathrm{N}$-methylene (2-benzoxazolo) aryl amide $(11,12)$, the IR spectra of compound (11) shows absorption peaks $v \mathrm{~cm}^{-1}$ at $3359(\mathrm{~N}-$ $\mathrm{H})$ and $1649(\mathrm{C}=\mathrm{O})$. 
$\mathrm{R} \longrightarrow \mathrm{COCl}+\mathrm{H}_{2} \mathrm{NCH}_{2} \mathrm{CO}_{2} \mathrm{H} \stackrel{1 \mathrm{~N} \mathrm{NaOH}}{\longrightarrow} \mathrm{R} \longrightarrow \stackrel{\mathrm{I}}{\mathrm{C}}-\mathrm{NHCH}_{2} \mathrm{CO}_{2} \mathrm{H}$<smiles>[R]c1ccc(C(=O)NCc2nc3ccccc3o2)cc1</smiles>

$(11,12)$<smiles>[R]c1ccc(C2N=CC3Oc4ccccc4N32)cc1</smiles>

$(13,14)$<smiles>Nc1ccccc1O</smiles><smiles>[R]c1ccc(C(=O)NCC(=O)Cl)cc1</smiles>

$(3,4)$ $\mathrm{NH}_{4} \mathrm{OH}$<smiles>[R]c1ccc(C(=O)NCC(N)=O)cc1</smiles>

$(5,6)$<smiles>O=C1CCCCC1Br</smiles><smiles>[R]c1ccc(-c2ncc3n2C2CCCCC2O3)cc1</smiles>

$(9,10)$
$-\mathrm{POCl}_{3}$<smiles>[R]c1ccc(C(=O)NCC2=NC3CCCCC3O2)cc1</smiles>

$(7,8)$

$\mathrm{R}=\mathrm{H}, \mathrm{NO}_{2}$

Scheme (1) 
The reaction proceed through the well-known tetrahedral mechanism, which can be shown in the following Scheme:<smiles>[R]c1ccc(C(=O)NC[C@]2(Cl)CCCCN(c3ccccc3O)CC[C@H]2C)cc1</smiles><smiles>[R]c1ccc(C(=O)NCc2nc3ccccc3o2)cc1</smiles>

Compounds $(11,12)$ were treated with phosphorous oxychloride to give 4-substituted benzoxazole [3,4-b] imidazole $(13,14)$. The suggested mechanism for the preparation of compounds $(9,10)$ and $(13,14)$ is illustrated in the following Scheme:

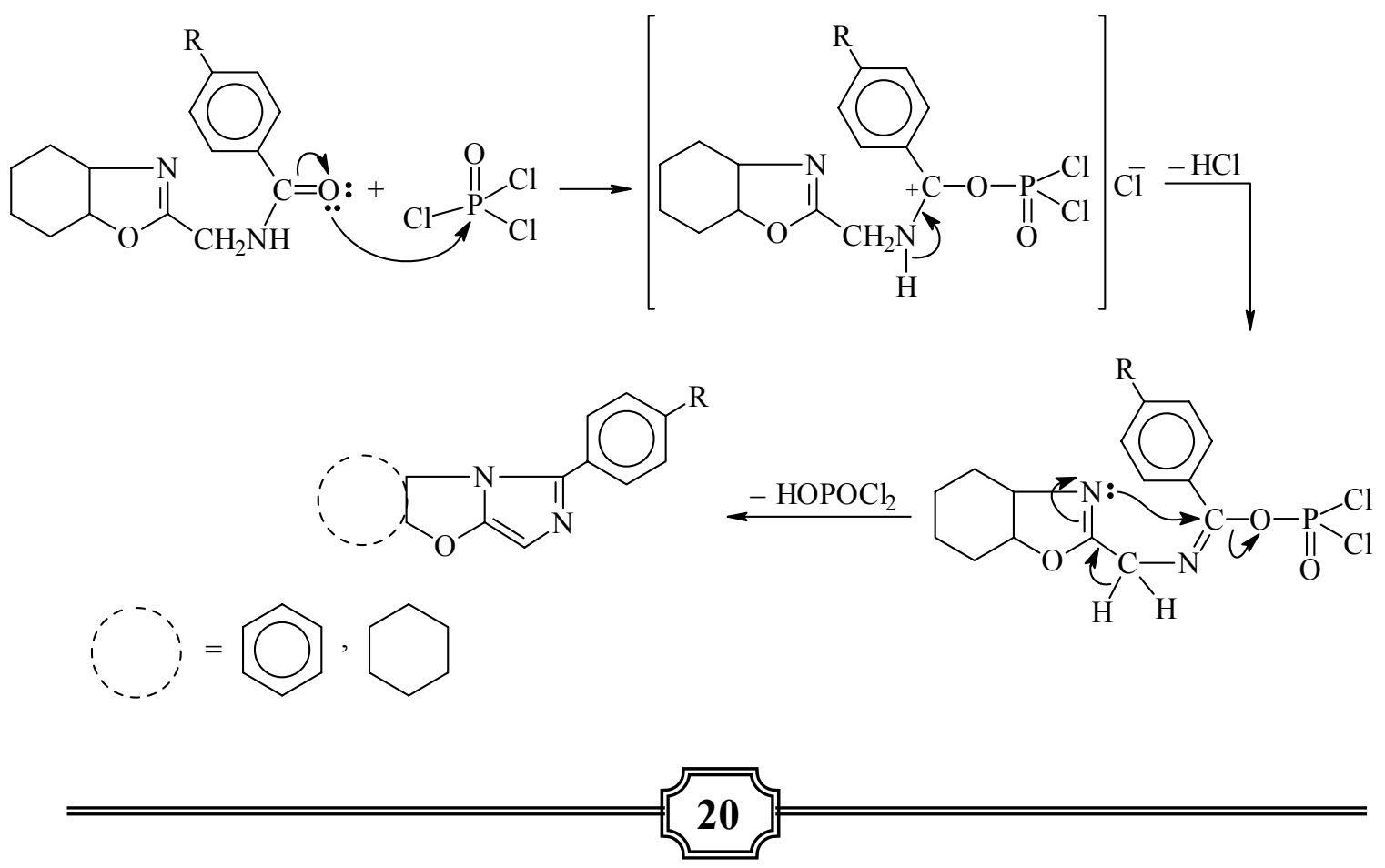


Synthesis of Some Substituted Benzoxazole [3,4-b] imidazoles.

The UV spectra for the synthesized compounds shows maximum absorption range $\lambda_{\max } 280-392 \mathrm{~nm}$ due to $n-\pi^{*}$ transition. The physical and spectral data for the synthesized compounds are shown in Tables (1 and 2).

Table (1): Physical properties of compounds

\begin{tabular}{|c|c|c|c|c|}
\hline Color & m.p. $\left({ }^{\circ} \mathrm{C}\right)$ & Yield (\%) & $\begin{array}{c}\text { Molecular } \\
\text { formula }\end{array}$ & Comp. No. \\
\hline White & $186-188$ & 92 & $\mathrm{C}_{9} \mathrm{H}_{9} \mathrm{NO}_{3}$ & 1 \\
\hline White-yellow & $212-214$ & 94 & $\mathrm{C}_{9} \mathrm{H}_{8} \mathrm{~N}_{2} \mathrm{O}_{5}$ & 2 \\
\hline Brown & $325 \mathrm{~d}$ & 90 & $\mathrm{C}_{9} \mathrm{H}_{8} \mathrm{NO}_{2} \mathrm{Cl}$ & 3 \\
\hline White-yellow & $163-165$ & 91 & $\mathrm{C}_{9} \mathrm{H}_{7} \mathrm{~N}_{2} \mathrm{O}_{4} \mathrm{Cl}$ & 4 \\
\hline Brown & $273-275$ & 95 & $\mathrm{C}_{9} \mathrm{H}_{10} \mathrm{~N}_{2} \mathrm{O}_{2}$ & 5 \\
\hline Yellow & $332-334$ & 95 & $\mathrm{C}_{9} \mathrm{H}_{9} \mathrm{~N}_{3} \mathrm{O}_{4}$ & 6 \\
\hline Brown & $211-213$ & 68 & $\mathrm{C}_{15} \mathrm{H}_{17} \mathrm{~N}_{2} \mathrm{O}_{2}$ & 7 \\
\hline Black & $100-102$ & 71 & $\mathrm{C}_{15} \mathrm{H}_{16} \mathrm{~N}_{3} \mathrm{O}_{4}$ & 8 \\
\hline Brown & $98-100$ & 60 & $\mathrm{C}_{15} \mathrm{H}_{16} \mathrm{~N}_{2} \mathrm{O}$ & 9 \\
\hline Brown & $82-84$ & 61 & $\mathrm{C}_{15} \mathrm{H}_{15} \mathrm{~N}_{3} \mathrm{O}_{3}$ & 10 \\
\hline Brown & $102-104$ & 67 & $\mathrm{C}_{15} \mathrm{H}_{12} \mathrm{~N}_{2} \mathrm{O}_{2}$ & 11 \\
\hline Red & b.p. $123-125$ & 61 & $\mathrm{C}_{15} \mathrm{H}_{11} \mathrm{~N}_{3} \mathrm{O}_{4}$ & 12 \\
\hline Brown & $90-92$ & 74 & $\mathrm{C}_{15} \mathrm{H}_{11} \mathrm{~N}_{2} \mathrm{O}$ & 13 \\
\hline Colorless & oily & 70 & $\mathrm{C}_{15} \mathrm{H}_{10} \mathrm{~N}_{3} \mathrm{O}$ & 14 \\
\hline
\end{tabular}

Table (2): I.R and U.V spectral data

\begin{tabular}{|c|c|c|c|c|c|c|c|}
\hline \multirow{2}{*}{$\lambda$} & \multicolumn{6}{|c|}{$\mathrm{I} . \mathrm{R} \vee \mathrm{cm}^{-1}(\mathrm{KBr})$} & \\
\hline & $\mathrm{C}=\mathrm{N}$ & $\mathrm{N}-\mathrm{H}$ & $\mathrm{C}-\mathrm{O}$ & $\begin{array}{c}\mathrm{C}=\mathrm{O} \\
\text { (amide) }\end{array}$ & $\mathrm{C}=\mathrm{O}$ & $\mathrm{O}-\mathrm{H}$ & \\
\hline 282 & - & 3172 & 1181 & 1630 & 1745 & 3341 & 1 \\
\hline 336 & - & 3116 & 1127 & 1639 & 1694 & 3414 & 2 \\
\hline 296 & - & 3445 & - & 1670 & 1770 & - & 3 \\
\hline 312 & - & 3421 & - & 1652 & 1730 & - & 4 \\
\hline $280-264$ & - & 3405 & - & 1623 & - & - & 5 \\
\hline 280 & - & 3410 & - & 1645 & - & - & 6 \\
\hline $314-300$ & 1636 & 3422 & 1031 & 1653 & - & - & 7 \\
\hline 286 & 1625 & 3405 & 1021 & 1647 & - & - & 8 \\
\hline 304 & 1601 & - & 1025 & - & - & - & 9 \\
\hline 302 & 1620 & - & 1040 & - & - & - & 10 \\
\hline $336-321$ & 1600 & 3359 & 1108 & 1649 & - & - & 11 \\
\hline 282 & 1658 & 3417 & 1021 & 1690 & - & - & 12 \\
\hline 302 & 1601 & - & 1026 & - & - & - & 13 \\
\hline $390-338$ & 1601 & - & 1025 & - & - & - & 14 \\
\hline
\end{tabular}




\section{REFERENCES}

1. Cornforth J. W. and Cornforth R. H., J. Chem. Soc., 96 (1947) 96.

2. Katritzky A. R. and Reez G. W., Comprehensive Heterocyclic Chemistry; Synthesis and Uses of Heterocyclic Compounds, Pergamon Press Ltd., England, 1984.

3. El-Sheikh M. I. and Marks A., J. Org. Chem., 46 (1981) 3256.

4. Finar I. L., Organic Chemistry. Stereochemistry and the Chemistry of Natural Products, Vol. 2, Edn. Longermans Green and Co Ltd., 1981.

5. Xenia Beebe, Dariuszwodka and Thomas J. Sowin, J. Comb. Chem., 3 (2001) 360-366.

6. Guey-Sheng Liou, Internet.

7. Kim J. Heung, Sang Woo Bang and Young June Kim, Bull. Korean Chem. Soc., 21 (2000) 9.

8. Yalcin I., Orer I., Temiz O. and Akisener E., Acta Biochimica Polonica, 47 (2000) 2.

9. Elamin E. I., Zubair M.U. and Al-Badr A. A., Antimicrobial Agents and Chemotherapy, 19 (1981) 1, 29.

10. Schiketanz I., Draghici C., Sarament I. and Balaban A.T., Arkivoc, (ii) (2002) 64-72.

11. Fieser L. F. and Fieser M., "Reagent for Organic Synthesis". Wiley, New York, 1, 286, 1997.

12. وليلم كيمب، تعريب د. جواد فياض و د.سلمان لحمدسلمان، "الكيمياء العضوية

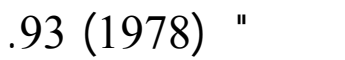

13. Anthony Marques M., The Molecular Recognition of DNA by Novel Heterocycles. Ph.D. Thesis, Chapter 12, 307, California Institute of Technology.

14. Sycheva T. P., Pankina Z. A. and Shchukina M. N., Chemistry of Heterocyclic Compounds, 6 (1976) 4.

15. El-Shafie A. K., El-Saghier A. M. M. and Ahmed E. A., Synthesis, (1994) 152-154. 